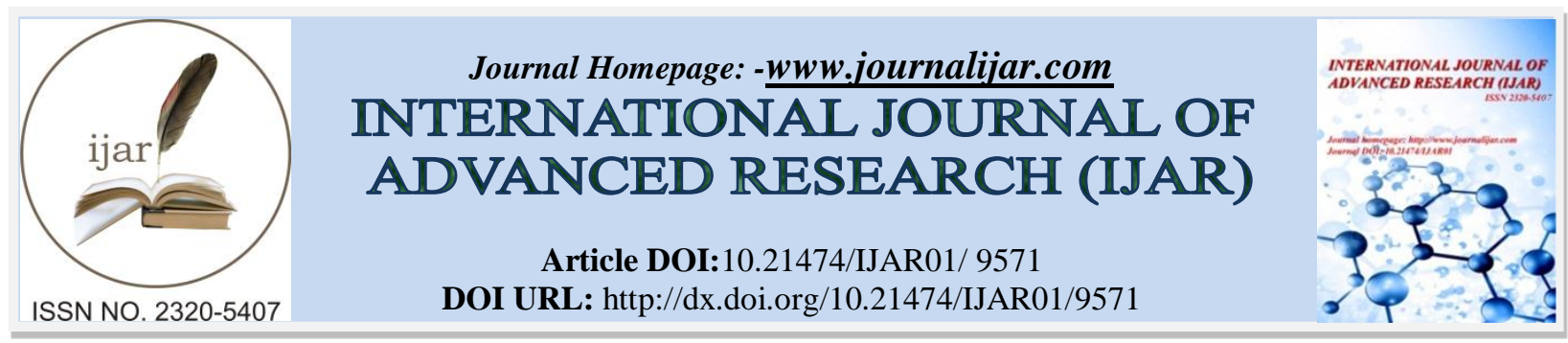

RESEARCH ARTICLE

\title{
TEACHING EFL WRITING AT THE SSC LEVEL IN BANGLADESH: CHALLENGES AND CONSIDERATIONS.
}

Md. Zahirul Islam ${ }^{1}$, A. F. M. Moshiur Rahman² and Md. Khorshed Alam³.

1. Lecturer in English, Govt. Mohammadpur Model School and College, Dhaka, Bangladesh.

2. M.Phil Fellow, Department of English, Islamic University, Kushtia, Bangladesh.

3. Lecturer in English, Hazi Misir Ali Degree College, Narayanganj, Bangladesh, and M.Phil Fellow, Department of English, Islamic University, Kushtia, Bangladesh.

\section{Manuscript Info}

[........................

Manuscript History

Received: 14 June 2019

Final Accepted: 16 July 2019

Published: August 2019

Key words:-

Writing Skill, SSC, EFL, Challenges.

\section{Abstract}

Teaching EFL writing is one of the challenging tasks for every teacher, especially at the secondary level of education as it is consisted of very young learners. The current study was conducted with the aim of examining the challenges faced by the EFL teachers teaching EFL writing at the SSC level in Bangladesh. Mixed Method Approach was applied to conduct the study. 4 EFL teachers were interviewed from four secondary school of Dhaka City and 60 SSC students were given questionnaire to collect data. The study also aimed at exploring learners' view regarding their learning of writing skill as well. It was explored from the teachers' interviews that they faced a number of common challenges while teaching writing at the SSC level including students' tendency of memorizing rather productive writing, large class size and short class duration, insufficient teachers' training and improper curriculum. It was unfolded from the students' questionnaire that most of them did not get sufficient vocabulary and idea for creative writing. They claimed that they often did spelling and grammatical mistake while writing. It was also found that learners did not get sufficient time for writing practice in the classroom and for the same issue teachers could not give them clear feedback on their writing script. Based on the findings of the study, it was recommended that trained teachers, more writing practice in the classroom, interesting visual materials, motivation, and quick and clear feedback were essential to overcome the challenges to teaching-learning of writing skill at the SSC level in Bangladesh.

Copy Right, IJAR, 2019,. All rights reserved.

\section{Introduction:-}

English has been being taught as a mandatory subject in our country for long period of time covering four major phases of education: primary, secondary, higher secondary and tertiary education. Secondary Level (SSC) of education is one of the largest phase of education in Bangladesh where English gets much importance as it covers 200 marks. The English text books of this level have been developed for the students to learn EFL listening, speaking, reading and writing skills through meaningful and enjoyable activities. Writing is considered the most 
important skill that students require in order to enhance their personal development and academic success (Mukulu et al. 2006). According to Nunan(1991)

"Writing is an extremely complex cognitive activity in which the writer is required to demonstrate control of variables simultaneously. At the sentence level, these include control of contents, format, sentence structure, vocabulary, spelling and letter formation. Beyond the sentence, the writer must be able to structure and integrate information into cohesive and coherent paragraph and text."

Writing is a process of communicating with others in which a writer sends his ideas and thoughts in written forms to readers. It is a process of thinking which the writer discovers, organizes, and communicates his or her thoughts to the reader (Wingersky, 1999, p. 4). Moreover, it is about conveying meaning by using words that have been chosen and put together in written or printed form (Farbrain \& Whinch, 1996, p. 32). In the academic context, students are required to produce specific writing genres such as essays, summaries and reports (Dudley-Evans, 2001). In SSC level writing covers total 90 marks: 50 marks in first paper and 40 marks in second paper. Students has to write paragraph, story, letter/email, chat description, dialogue, CV and composition. It means that being skilled in EFL writing is one of the major focus at the SSC level in Bangladesh. Richards (2008) notes that learning to write in either first or second language is one of the most difficult tasks students encounter and one that few people can be said to fully master. Tangpermpoon (2008) points out that when compared with other language skills of listening, speaking and reading, writing is the most difficult skill to learn because it requires writers to have a great deal of lexical and syntactic knowledge as well as principles of organization in L2 to produce a good written text.

The ability to write appropriately and effectively is considered a major part of written communicative competence among students at all levels of the education system. However, learning to master writing skills is a problem that students face in secondary schools. Difficulties of teaching the writing skills of the English language are reportedly one of the most challenging tasks which are not only experienced by native speakers but also the English Second/Foreign Language teachers around the globe. Due to the increased demands that the academic writing place on the students for delivering an effective English language writing sample, it is therefore necessary to carry out an investigation to gauge whether or not the English Second/foreign Language teachers had to face difficulties in teaching writing skill. Good writing requires preparation and suitable feedback, which teachers must never underestimate.

Though the ministry of education and other educational authorities have already taken different initiatives to improve the English language teaching and learning condition at the SSC level in Bangladesh, there are so many constraints to the teaching learning process of English. Specially, teachers face different types of challenges while teaching EFL writing at the SSC level in Bangladesh and the students also encounter different challenges when practicing EFL writing in the classrooms. Generally, teachers face problems regarding authentic materials, classroom size and teaching-learning environment, students' background knowledge etc. So, it is important to examine the pedagogical challenges faced by the teachers when teaching EFL writing at the HSC level. The aim of this study is to find out the challenges faced by the teachers when teaching EFL writing at the SSC level in Bangladesh, and provide research based recommendations.

\section{Literature Review}

Many studies have already been carried out regarding the different issues of writing in different level of education. Reviews of a number of studies have been unfolded in this portion to connect the core issues with the present study.

Eyinda and Shariff (2010) carried out a study to investigate the teaching of writing in an ESL classroom in secondary schools in Kenya. The findings of the study indicated that most teachers dominated in the classroom interaction. It was also reported that teaching methods used were mainly teacher centered such as lecturing and question and answer. The study's findings further indicated that although teachers use a variety of teaching and learning activities in their writing lessons, most of the activities used give teachers overwhelming control of the class proceedings. Teachers also face challenges such as lack of knowledge, skills and interest to teach writing, inadequate teaching and learning resources, large classes and lack of learners' interest in writing. From the findings of the study, it was recommended that teachers need to explore the use of learner centered activities such as peer editing, role play and group discussion to enhance development of students' writing skills. Cur- riculum developers also need to produce more curriculum support materials for teaching writing and sensitize teachers the best way to implement the integrated English syllabus. 
According to Hartfiel, Hughey, Wormuth, \& Jacobs (1985), a good writing has to consider some aspects of writing; grammar, vocabulary, mechanic, content, and organization. Brown (2000) opined that the role of the teacher, therefore, has to be one of facilitator and coach, not an authoritative arbiter. As a facilitator, the teacher offers guidance in helping students to engage in the thinking process of composing but, in a spirit of respect for student opinion, must not impose his or her thoughts on student writing.

Richard (1990) mentioned that learning to write either in the first or second language is one of difficult tasks a learner encounter. .(Kellogg, 1999) has nicely pointed out that the teachers' tasks are certainly to explore students' stimulus for writing, which, contains attainment motivation, fundamental motivation, and extrinsic motivation, which is believed to assist the teachers plan meaningful and significant writing tasks by taking into account the students' level of motivation. Myles (2002) mentioned that for teachers to motivate students in writing for academic purposes, they should encourage students to read academic texts and work with other students who are more acquainted with the discourse. However, if they do not engage in the text or actively contribute during the study sessions, these activities will have little effect on students' progress. Thus, if students are motivated to write in L2, they will develop a higher level of proficiency and positive attitudes, which can have a positive effect on their writing. In addition, Jarvis (2005) said that in order to motivate students in L2 writing, teachers should write positive comments on learners' exercise books and verbally reinforce good language responses as part of their instructions.

Atkinson (2002) mentioned that some learners are not particularly concerned about their writing, while others are. The extent to which learners' intrinsic motivation propels them toward improvement will impact their reading habits as well. The teacher does not have other choice except to try to wake learners' motivation. The problem is that motivation is a very complex thing. Motivation means a cluster of factor that 'energizes' the behavior and gives it 'direction'. Reading habit which is known to be much related to someone's writing ability also need attention. (Grabe and Kaplan, 1997) stated that educationally oriented second language learners may need to develop writing skills, and in relation to this, teachers may equally need to equip themselves with the knowledge and skills of how to teach writing skills. As has been reported in some studies, most of the second language teachers find writing rather a complex skill to teach by aptly linking it with their students' learning outcomes. Shaywitz (2003) believed that teachers are required to know that students learn in different ways, hence it may require different assets and requirements. For example, a low- achieving student in writing may not be necessarily be a low-achiever in other aspects of academic achievement. Every student with writing problems may have their own learning style, interests, requirements, and assets. In this regard, it is the teachers who should be able to help the students to identify their interests and strengths.

\section{Significance of the Study}

The central goal of the study is to explore the real scenario of teaching EFL writing at the SSC level in Bangladesh. Though a number of research works have already been conducted in this field, they are not sufficient and to the specific point as the current study focus. The present study carries significance because it will give us significant insights about the different issues related to the teaching EFL writing at the SSC level. The study has immense possibility to offer teachers with key insights about the usefulness of different techniques for teaching EFL writing. Furthermore, teachers and learners will get chance to explore their insight through this study. Moreover the findings of this study would serve as a basis for assisting EFL teachers adopt teaching strategies that will enhance learning of writing skills among students. Then, the study would enable curriculum developers and textbook writers to come up with materials that will address the challenges students face in EFL writing. The researcher also hoped that the findings of the study would be relevant in teacher education as a whole, especially regarding language education which may enable teacher trainers to come up with better methods of training language teachers with specific reference to writing skills.

\section{Objectives of the Study}

The aim of the current study is to identify the problems which English teachers face while teaching EFL writing at the SSC level and focus the considerations. It is important to sketch the real scenario of teaching and learning EFL writing at the SSC level in Bangladesh that the teachers and the students face. The objectives of the study are divided into two parts.

\section{General Objective}

To explore the challenges in teaching EFL writing at the SSC level in Bangladesh. 


\section{Specific Objectives}

1. To examine the problems teachers face while teaching EFL writing at the SSC level

2. To investigate the problems students encounter while learning EFL writing at the SSC level

3. To propose research-based suggestions and recommendations for overcoming the constraints on the way of teaching EFL writing at the SSC level.

\section{Research Methodology:-}

Mixed Method Approach (MM) was applied to conduct the present study. The study took place in four Secondary level schools of Dhaka City. 4 EFL teachers were interviewed and 60 students, 15 from each school were given questionnaire to have their opinion regarding the respective arena of the current study.

\section{Findings and Discussion:-}

This section is concerned with the findings of the study. The results are presented in two main sections. Since the responses were actually on a binary scale, the two categories of 'strongly agree' and 'agree' were collapsed into single category agreement, while 'strongly disagree' and 'disagree' were collapsed into single category disagreement to allow easier discussion of the results. The statements assessing the expected response of the participants were adopted through a five-point Likert scale (Likert, 1932). On the scale, statements were coded as Strongly Agree=5, Agree=4, Neutral=3, Disagree=2, and Strongly Disagree $=1$.

\section{Findings from Teachers' Interviews}

All the four interviewed teachers claimed a number of common problems they faced while teaching EFL writing at the SSC level. Most of the time while teaching writing skills in the classrooms, teachers observed that most of the students were unwilling to practice productive writing because they were habituated in writing by memorizing. Even they felt bored and shy of making mistakes. They were not interested to produce their own sentences rather they were more concerned to blind memorizing. Even sometimes students tried to escape from writing skills class.

Again, all the teachers opined that class duration was too short to practice writing because it needed more time to make the students mentally and physically prepared to gather idea on a topic and to practice writing in individual or group. They also believed that it was quite impossible to give clear feedback to students' written scripts for time constraints and large class size. Most of the teachers mentioned that it was difficult to teach writing properly in the classroom because of some common problems of the students as well that included different background level of students, poor knowledge of grammar and vocabulary, and lack of reading practice for the idea of productive writing. Most of the teachers said that they applied communicative method to teach writing skills so that students could get interested in writing and they encouraged them to read English newspapers, books and magazine regularly to learn the basic structure of sentences and uses of words and idioms and phrases.

Most of the teachers believed that the curriculum of S.S.C level was not completely appropriate and adequate. They thought that more emphasis should have been given to writing skills in the curriculum of S.S.C and more lessonwise exercises of writing skills should be developed. All of the teachers added that they had very little opportunity to deal with other supporting materials to teach writing skill at the SSC level other than the Textbook. Two of the teachers mentioned that they needed more teachers' training to teach writing more interestingly.

\section{Findings from Students' Questionnaire}

This section deals with the response of the students regarding the challenges they face while learning EFL writing.

\begin{tabular}{|l|l|l|l|}
\hline Statement & Agree & Disagree & Neutral \\
\hline $\begin{array}{l}\text { I can make correct and } \\
\text { meaningful sentences }\end{array}$ & $47(78.33 \%)$ & $11(18.33 \%)$ & $02(3.33)$ \\
\hline $\begin{array}{l}\text { I get sufficient idea while } \\
\text { writing }\end{array}$ & $25(41.67 \%)$ & $27(45 \%)$ & $08(13.33 \%)$ \\
\hline $\begin{array}{l}\text { My vocabulary level is } \\
\text { sufficient for academic } \\
\text { writing }\end{array}$ & $12(20 \%)$ & $39(65 \%)$ & $09(15 \%)$ \\
\hline $\begin{array}{l}\text { We frequently do writing } \\
\text { practice in the classroom }\end{array}$ & $07(11.67 \%)$ & $51(85 \%)$ & $02(3.33 \%)$ \\
\hline
\end{tabular}




\begin{tabular}{|l|l|l|l|}
\hline $\begin{array}{l}\text { Teachers give feedback of } \\
\text { our writing regularly }\end{array}$ & $05(8.33 \%)$ & $48(80 \%)$ & $07(11.67 \%)$ \\
\hline
\end{tabular}

Table 1:-Student Questionnaire

In response to the first question, 78.33\% (frequency-47) students opined that they could make correct and meaningful sentences. $18.33 \%$ (frequency-11) disagreed regarding the same statement and another 3.33\% (frequency-02) students were neutral to the same statement. In case of the second question $41.67 \%$ (frequency-25) students believed that they got sufficient idea while writing. In response to the same statement, $45 \%$ (frequency-27) students disagreed and $13.33 \%$ ( frequency-08) were neutral.

Regarding the question number three, $20 \%$ (frequency-12) students agreed that their level of vocabulary is sufficient for academic writing. 65\% (frequency-39) students disagreed regarding the same statement. In answering to the same question, $15 \%$ ( frequency-09) students were neutral. Answering the question number four, $11.67 \%$ (frequency07) students opined that they frequently did writing practice in the classroom. 85\% (frequency-51) students disagreed. In answering to the same question, $3.33 \%$ ( frequency-02) students were neutral.

In response to the question number five, $8.33 \%$ (frequency-05) students agreed that teachers gave feedback of their writing regularly. $80 \%$ (frequency-48) students disagreed regarding the same statement. In answering to the same question, $11.67 \%$ ( frequency-07) students were neutral.

\section{Discussion Based on the Findings of the Study}

Through the cross-checking of the findings from teachers' interview and student questionnaire, it can be easily said that the common challenges of teaching-learning of writing skill at the SSC level covers insufficient time allocation for writing practice, memorizing tendency of the learners, improper feedback from the teachers, lack of writing idea and vocabulary, poor classroom writing practice, lack of teachers' training and the insufficient supporting materials in the classrooms. So, it is essential to look at those shortcomings and take practical initiative to improve the situation.

\section{Limitations of the Study}

The present study had a number of limitations. This study was confined to only four secondary schools of Dhaka city that could not give the picture of the whole country. It also dealt with only a limited number of participants and employed only three techniques to collect data. So, the study had some shortcomings regarding unavailability of necessary data, information, literature and other relevant materials. Besides, the study has made no variable in the analysis of the findings in respect of gender, geographical region, and social condition.

\section{Conclusion and Recommendations:-}

The total scenario of teaching-learning of writing skill at the SSC level in Bangladesh is not satisfactory. The low standard of EFL writing in the country has always been a matter of concern to all language learners and teachers. Both of the students and teachers agreed regarding some common challenges they often face to improving writing skill. So, the study is potentially significant in that it will offer important insights into teaching EFL writing at the SSC level in Bangladesh. Most importantly, it will highlight the voices of teachers and students, the very important people at the center of the teaching and learning process. Based on the findings and discussion, a number of recommendations to improve the present scenario of writing skill at the SSC level in Bangladesh are as follow:

1. Ministry of education, education board and school authority should arrange teachers' training on regular basis, excellent classroom environment and sufficient teaching writing materials.

2. School authority and the teachers should allocate more time duration for teaching EFL writing.

3. Classroom writing practice should be given more emphasis.

4. Learners have to be given individual, peer and group writing tasks on interesting topics

5. Teachers should arrange more visual materials in the classrooms to elicit writing idea for the learners.

6. Teachers should provide clear and quick feedback on the writing tasks where errors would be marked and correction note would be given clearly.

7. Vocabulary, spelling and grammar should be taught through game, story and other fun activities. 


\section{References:-}

1. Atkinson, R. K. (2002). Optimizing Learning from Examples Using Animated Pedagogical Agents. Journal of Educational Psychology.

2. Brown, H. D. (2000). Teaching by Principles (2nd Edition ed.). San Francisco: Longman.

3. Dudley- Evans, T. (2001).English for specific purposes in the Cambridge guide to TESOL: Cambridge: Cambridge University Press.

4. Farbrain, G., \& Whinch. (1996). Reading, Writing and Reasoning. Boston: Houghton Mifflin Company.

5. Grabe, W.,\&Kaplan,,R. B. (1996). Theory and practice of writing: An applied linguistic perspective. London: Longman.

6. Hartfiel, Hughey, Wormuth, \& Jacobs. (1985). Learning ESL Composition. Rowley:Newbury House Publisher, Inc.

7. Jarvis, M. (2005). The Psychology of effective Learning. Cheltenham : Nelson Thornes.

8. Morris L. (1996). Interaction in the language classroom: Awareness, Autonomy and Authenticity. Harlow: Longman.

9. Mukulu, E.,Indangasi, H., Mwangi, P., Gecaga,C. \&Okanga, N. (2006.) KCSE revisionEnglish. Nairobi.Kenya Literature Bureau.

10. Myles, J. (2002). Second language writing and research: The writing process and error analysis in student texts. Teaching English as a second or foreign language Journal, 6(2),1-19.

11. Nunan, D. (1991). Language teaching methodology: A textbook for teachers. Edinburgh, Harlow, England: Longman.

12. O' Malley, J.,\& Chamot, A. (1990).Learning strategies in second language acquisition.New York: Cambridge University Press.

13. Richards, J.C (2008). Second language teacher education today. RELC Journal, Vol. 39,158-177.

14. Richard, J. C. (1990). The Language Teaching Matrix. New York: Cambridge UniversityPress.

15. Robert, G. (1997). Statistical Methods for Education. New York: Prentice Hall.

16. Shaywitz, S. E. (2003). Overcoming dyslexia: A new and complete science-based program for reading problems at any level. Knopf.

17. Tangpermpoon, T. (2008).Intergraded approaches to improve students' writing skills for English major students. ABAC Journal, Vol. 28, 1-9.

18. UNESCO (1996). The Quality of Primary Schools in Different Development Context,IIEP, UNESCO, Paris

19. Wall, D. \& Alderson, C. (1996). Examination washback: the Sri Lankan Impact study. In A., Cumming \& R. Berwick (Eds.), Validation in language testing (pp. 194- 221). Philadelphia: Multilingual Matter

20. Wingersky. (1999). Writing Paragraph and Essays Integrating Reading, Writing and Grammar Skills. London: Wadsworth Publishing Company. 